\title{
Morality and EFL Instruction in an Arab Context - Exploring Perceptions and Practices
}

\author{
Antar Abdellah $^{1} \&$ Mahdi Ibrahim ${ }^{2}$ \\ ${ }^{1}$ College of Education, Taibah University, Medina, Kingdom of Saudi Arabia \& South Valley University, Egypt \\ ${ }^{2}$ College of Education, Taibah University, Medina, Kingdom of Saudi Arabia \& Suez Canal University, Egypt \\ Correspondence: Antar Abdellah, College of Education, Taibah University, Medina, Kingdom of Saudi Arabia, \\ PO.B 344. E-mail: antar20@aim.com
}

This research is financed by the Deanery of Scientific Research at Taibah University, KSA. The researchers would like to thank Tiabah University for its support and encouragement.

Received: March 12, 2013 Accepted: April 8, 2013 Online Published: April 12, 2013

doi:10.5539/elt.v6n5p81 URL: http://dx.doi.org/10.5539/elt.v6n5p81

\begin{abstract}
This study was conducted to investigate the correlation between moral commitment and EFL teacher standard-based performance. 20 Muslim English native speaking instructors who work at Taibah University Language Centre participated in this study. The following instruments were used for investigating the correlation between teachers' moral spirituality and their practical classroom performance: a scale of religious commitment, an open-ended questionnaire of spirituality and a standard-based observation sheet of the teachers' performance. The present study sheds light on the nature of moral commitment and its correlation to EFL teacher performance based on different personal conceptions about Islam.
\end{abstract}

Keywords: morality, spirituality, religion, commitment, EFL instruction, native speakers

\section{Introduction}

Research around the role of spirituality, morality and belief in general in language teaching and learning can be traced to Palmer 1983. Palmer investigated the effect of a person's belief and values system on second language acquisition. Two decades later, Leather and Van Dam (2003) followed the same track by exploring the effect of the social, cultural and interpersonal environment on foreign language learning and acquisition. Within the same vein, different researchers sought to find the correlation between second language learning and different environmental factors; ELT and cognition (Croft and Cruse, 2004), sociology (Labov, 1972), psychology (Chomsky, 2000; Lakoff, 1987), politics (Pennycook \& Coutand-Marin, 2003), and in recent years, values (Johnston, 2003) and ecology (Krasmch, 2002).

Spirituality has been regarded as a hidden power. In Pope Paul VI's words, "from ancient times down to the present, there is found among various peoples a certain perception of that hidden power which hovers over the course of things and over the events of human history; at times some indeed have come to the recognition of a Supreme Being. This perception and recognition penetrates their lives with a profound religious sense" (1965). Stevick (1990) describes spirituality as the assumptions and values systems that lie behind people's behavior. In Palmer's words, it is "the eternal yearning for something larger than us" (2003: 376). It is an inclusive concept that covers how spirituality involves the individuals' language learning / teaching processes.

Hong, (2007: 13) claims that "Spiritual ecology proposes that spirituality permeates the socio-cultural and institutional context where individual learners/instructors' learning or teaching happens". Cranton and Carusetta (2004) distinguish two types of personalities embedded in the EFL teacher's career; namely the private persona and the public (classroom) persona. They found out that most experienced teachers in higher education tend not to separate the two types of persona in their pedagogical practices. On the same track, Hong (2007) described a sketch of how Christianity as a spiritual value system influenced the work of EFL leaders including TESOL Quarterly former presidents. She found out that all of the interviewees agreed on the inseparable role of religious morality in their language teaching career. 
Stevick (1990) declares that faith is inseparable of practice; "we function best when faith, experience and intellect are in harmony". In his view, a language learner may even seek strength from his/her faith to support the process of language learning. This may have allusions in the early history of Arab and Muslim scholars learning a foreign language. Abdellah (2012) for example handled the foreign language learning strategies employed by Muslim religious scholars. He took the example of Imam Muhammad Abduh and Sheikh Salman Al Ouda; an Egyptian $19^{\text {th }}$ century liberal judge and a Saudi $21^{\text {st }}$ century moderate preacher. He found out that in both cases religion was the driving force behind these scholars' endeavors to learn a foreign language. It is this moral and spiritual force that led Abduh to learn French and master ancient Arabic grammatology, and that led Al Ouda to learn English while in prison. (Abdellah, 2012).

For Johnston (2003), the nature of a language teacher's career is human only through the interplay of values in the classroom. He states: "we should re-examine our values and how they play out in the given circumstances; the morality of our decision making lies in the encounter between our own values and the complex details of particular contexts and cases.

It is this that makes our work so difficult; yet it is also this that makes it profoundly human and profoundly meaningful" (p. 47).

Layder (1993) proposed a framework for examining the areas in which the role of religious belief in language learning might be open to investigation. He suggests four contexts of inquiry in research into language and spirituality - sociocultural structures, institutional contexts, communicative practices, and individual experiences.

According to Ren (2009: 183), "One can usually accomplish nothing if he/she regards the occupation as a job, while his/her achievement tends to be uncommon if he/she regards the occupation as a [moral] career. If we regard the occupation just as an occupation, then what's on our mind is only a job, and a means of subsistence. However, if we regard the occupation as a career, then it will become an indispensable part of our life. We will have the enthusiasm to go forward with a strong push-and-go and desire of learning, and pursue realization of the value of our life".

We finish this part by the saying of the Italian Poet Dante; "Morality, in most cases, can fill up the defect of wisdom, while wisdom can never fill up the defect of morality." (in Ren 2009: 183).

\section{Review of Literature}

Fenstermacher, Osguthorpe and Sanger (2009) conducted a study to differentiate between teaching morally and teaching morality. They indicate that there are two ways of teaching morality; through manners and through content. For them, "a teacher who acts morally teaches morality through his or her manners. Modeling is the most prominent for of teaching morality through manner." (p. 8). They consider this form of teaching morally as more effective than teaching morality as the topic of instruction. Their study took place over three years in two schools; one was a k-5 elementary school in a small city; the other, a k-8 school in a large urban area. Both schools had previously adopted a moral education program consisting primarily of explicit attention to virtues as fairness, tolerance, responsibility, courage, honesty and cooperation.

The purpose of their study was to compare the practices of teachers in both schools as to their moral practices. The researchers examined the connections between moral manner and moral content more closely. They sought to see the ways teachers imparted moral ideas and ideals to their students. The researchers encountered six methods used by most teachers in both schools; 1 - the construction of the classroom community, 2- showcasing specific students, 3- design and execution of academic task structures, 4- calling out for conduct of a particular kind, 5- private conversations, and 6- didactic instruction. A final conclusion, the researchers reached is that "an adequate moral education seems to come not so much from attending to moral curriculum itself, but from having the teacher in a relationship of moral engagement with the student" (p. 13)

Khan (2004) compared the perspectives of immigrant and American teachers with regard to the moral development of students at Islamic schools in America. He draws his study based on the consensus, he found out, among both immigrant and American teachers in their general perceptions of what morality entails. "Teachers agree that the school vis-à-vis its social policies, attempts to provide a clear moral framework for the students so that they quickly learn what is Islamically 'appropriate' and 'inappropriate'." (p. 5). Khan notices that within the classroom, there are six primary processes by which teachers develop morality: "(i) integration of Islam and Islamic-related values into the daily lesson; (ii) dress code; (iii) male-female student interaction; (iv) identity development; (v) discipline; and (vi) Islamic Studies class" (p. 7).

Results of Khan's study showed that Immigrant teachers use the Quran to ground the emphasis on these particular virtues because they are mentioned so frequently in it. Furthermore, immigrant teachers teach their students to 
model their lives after the life of the Prophet Muhammad especially in situations where they have to respond to difficult social conditions such as hostility towards Muslims in America. Students are taught that if they lead their lives according to the prescriptions of the Quran and the Prophet Muhammad, they will be rewarded by Allah. On the other hand, American teachers continuously ask their students to evaluate a complicated situation on their own. They are encouraged to assess the circumstances from the Muslim beliefs taught in school and come to their own conclusions about whether a particular event, action, or behavior was "Islamically appropriate" or not. The teachers claim to provide their students with a clear moral framework from which they conduct their social lives, with the hope that students will apply this framework throughout the course of their daily interaction both within the Muslim community, but more importantly in their interactions with the greater American society.

Yost (1997) highlights the results of a qualitative study on the beliefs and views of graduates of a teacher education program. Through an integrated set of experiences, the program emphasized analysis and reflection of student, classroom, and community issues to develop moral decision making and critical reflection among pre-service teachers. Her study included four dimensions of morality teaching. Results showed that "two aspects of the moral dimensions relate to the role of the teacher: enculturating the young in a social and political democracy and providing access to knowledge for all children and youth. The two remaining components pertain to the characteristics of teachers: practicing pedagogical nurturing and ensuring responsible stewardship of schools." (p. 13). Based on these results, Yost suggests that teachers be provided with the knowledge base and belief systems enabling them to fulfill this mission. "Teacher education programs must help preservice teachers learn to reflect critically on student, school, and community issues and make ethical decisions" (p. 12). However, Yost's study raises serious questions about the efficacy of teacher education programs to prepare future teachers for their roles as moral educators who possess the necessary knowledge, thinking skills, and insight to provide a quality education for all students.

Ren (2009) tried to seek a framework for improving the overall quality of teachers in vocational education through the improvement of moral traits. "Improvement of moral trait is the foundation, improvement of cultural awareness the key, improvement of innovative quality the core, and improvement of health and psychological quality is the basis" (p. 179). He found out that improvement of morality should be based upon emphasis on cultivation of personality power. Teachers should get down to teaching, display their rich spiritual life and pursuit of distingue ideal without cease, and bring the role of teaching into a full play with their perfect personality charm and diligent and joyous working attitude.

Francis (2007) reports on a study that analyzed six Languages Other Than English (LOTE) teachers' reports about their teaching. Under the broad category of caring as a moral dimension of teaching, three major moral/ethical concerns were identified: (1) the concern that everyone has a worth, (2) the concern that students should not hurt each other's feelings, and (3) the concern that students should learn to tolerate differences. These concerns enveloped the teachers' stated goals of LOTE teaching and framed their behaviors in the classroom. Participants of the study were six LOTE teachers in regional Queensland, Australia who volunteered to participate in this study. Two were teaching a LOTE at primary (elementary) level, while the other four were teaching at secondary (high school) level. The teachers ranged in age from early $30 \mathrm{~s}$ to late $50 \mathrm{~s}$ and exhibited a wide range of teaching experience, from 3 to 30 years. The LOTEs taught by these teachers covered Chinese, German, Indonesian and Japanese. Data were collected through two semi-structured interviews, and two video-stimulated recall exercises. The overall framework comprised the following elements: goal focus, theoretical assumptions, strategies, social system (teacher roles, student roles, teacher-student relationships, normal student behaviors), principles of teacher reaction (p. 12).

Results showed that participants' teaching incorporates socio-moral goals. These are long-term goals that go beyond teaching a second language and its culture. There are certain values, or moral goals, that these teachers want to achieve through their teaching. Their caring involves affection, regard and feeling, but it seems to go beyond that and borders on the realm of ethical behavior. Based on these results, Francis recommends that teacher educators should develop a framework that will help understand the importance of the role of moral beliefs amongst the other beliefs that underpin teacher action in classroom.

\section{Context of the Study}

\subsection{Problem of the Study}

As a big number of English native speaking language instructors work in preparatory programs in Saudi Universities, the question of whether these teachers are reflecting quality standard-based teaching is always there. One dimension of good teaching is perceived to be moral commitment. Whether or not moral /religious commitment has a correlation to quality standard-based teaching is the main interest of the present study. Such 
correlation can provide insight unto the nature of morality and philosophy of teaching held by a sample of native speaking teachers hold and the relation of their view of morality to their professional ELT practices.

\subsection{Questions of the Study}

The study seeks to find answers to the following questions:

1- What is the nature of moral / religious commitment held by a sample of ELT native speaking instructors?

2- To what extent do the selected ELT teachers represent moral / Islamic committed practices?

3- How do the selected ELT teachers view themselves and their professional practices in the light of moral / religious standard practices?

4- What is the nature of the correlation between the selected ELT teachers' moral/ religious commitment and their standard-based practices?

\subsection{Purpose of the Study}

The study seeks to investigate the correlation between Islamic commitment and EFL teacher performance through exploring the selected ELT teachers' viewpoints concerning their understanding of moral / Islamic commitment, and comparing that with their observed standard-based practices.

\subsection{Substantial Value of the Study}

The present study seeks to shed light on the nature of moral Islamic commitment held by a sample of native speaker teachers at Taibah University. This dimension of the attributes of effective language teachers is perceived as important especially as rare studies have been conducted to investigate this factor within the Islamic faith. It is a deep journey unto the mind and soul of Muslim native speaker teachers of English to Muslim Arab students in the second holy city in Islam. A variety of views and practices are encountered which reflect the pluralist nature of Islamic moral commitment. It is hoped that the results of this study can work as an eye opener for teachers, course designers, decision makers and students to the mentality of native speaking ELT teachers working in the Arab world.

\subsection{Hypotheses of the Study}

1- The nature of moral / religious commitment held by a sample of ELT native speaker instructors is hypothesized to be of a diverse nature.

2- The selected ELT teachers are hypothesized to represent moral / Islamic commitment on a high positive level.

3- The selected ELT teachers are hypothesized to view their professional practices as falling short of their moral/ religious commitment.

4- There is a positive correlation between ELT teachers' moral/ religious commitment and their professional standard-based practices.

\subsection{Methodology of the Study}

The study follows an analytical approach in assessing the teachers' perspectives, and an evaluative approach in observing teachers' performance in the classroom. It is a correlative study with respect to the main purpose of the study; investigating the nature of the correlation between moral/ religious commitment and EFL standard-based practices.

\subsection{Delimitations of the Study}

The study is delimited to the following dimensions:

1- Only native speaking teachers of English; as it is assumed that teacher talk in the classroom includes metalanguage (language for instructions, for advising, for routine procedures in the classroom, and language for personal speech). Moral commitment in language can be fore-grounded quite well during the different uses of metalanguage. Since teachers who share the native language of their students tend to restore to the mother tongue in most metalanguage practices, this cannot be considered a professional target-language practice. However, this is perceived as genuine professional practice if delivered in the target-language. Thus English native speakers who do not speak Arabic have been chosen to represent the sample of the study.

2- Only male teachers are included due to the segregation policy in the Kingdom of Saudi Arabia whereby the researchers cannot observe female teachers. 
3- Taibah University, English Language Centre (ELC) is the place chosen for conducting the study, because it represents one of the highly populated areas with native English speaking instructors who prefer to live in the second holy city of Islam.

4- Only three observations are carried out for each participant, and an average value is calculated based on a standardized observation sheet.

\subsection{Instruments of the Study}

1. A scale of religious commitment. This was designed by the researchers to assess English language teachers' Islamic practices. It includes 30 items, to which respondents have to select a choice from "always, sometimes, or never". Reliability of the questionnaire items has also been established, and Alpha was found to equal 0.860 , which is a highly reliable value. (see appendix A)

2. An open-ended questionnaire / opinionnaire on the nature of spirituality / morality. To understand and interpret the quantitative data obtained for the first questionnaire, this open-ended questionnaire was designed to assess participants' qualitative responses which highlight and explain their responses to the scale of religious commitment. It is composed of ten Wh questions where participants are required to answer at their own pace and as they wish drawing on their personal ideologies. (See appendix B).

3. A standard-based observation sheet. This sheet was developed by the researchers to evaluate the teaching performance of the sample of the study. The sheet included four dimensions/standards for observation (Lesson objectives, lesson delivery Teacher-Student Interaction, and lesson closure). Each participant was observed three times by three different observers (the researchers plus a third expert in teacher education from the department of Curriculum). An average score was given to each teacher based on the three scores obtained by the three different observers. (See appendix C). Inter-rater reliability was calculated by analyzing the correlation between the three different raters, and the correlation coefficient is shown below in table 1:

Table 1. Inter-rater reliability for the instructors' observation sheet

\begin{tabular}{lllll}
\hline & & Evaluator_1 & Evaluator_2 & Evaluator_3 \\
\hline \multirow{2}{*}{ Evaluator_1 } & Pearson Correlation & 1 & $.980^{* *}$ & $.987^{* *}$ \\
& Sig. (2-tailed) & & .000 & .000 \\
& $\mathrm{~N}$ & 20 & 20 & 20 \\
& Pearson Correlation & $.980^{* *}$ & 1 & $.978^{* *}$ \\
Evaluator_2 & Sig. (2-tailed) & .000 & & .000 \\
& $\mathrm{~N}$ & 20 & 20 & 20 \\
& Pearson Correlation & $.987^{* *}$ & $.978^{* *}$ & 1 \\
Evaluator_3 & Sig. (2-tailed) & .000 & .000 & \\
& $\mathrm{~N}$ & 20 & 20 & 20 \\
\hline **. Correlation & is significant at the 0.01 level (2-tailed). & \\
\hline
\end{tabular}

\subsection{Procedures of the Study}

1- A meeting was held with 40 native speaking ELT instructors at Taibah University, where the researcher explained the nature and purpose of the study and invited the teachers to participate.

2- Since speaking about one's religious practices and moral commitment is perceived by many to be a private issue and since many do not like to speak openly about their faith and spiritual beliefs, participants were asked to hide their identities from the researchers, and were given codes for the correlation purposes rather than any real identification indicator.

3- Only 20 teachers agreed to participate in the study.

4- $\quad$ For the sake of credibility, teachers were observed and their teaching performance was evaluated before they were asked to respond to the scale of religious commitment and the open-ended questionnaire.

5- Teachers were then asked to respond to the two other instruments (the scale and the questionnaire) online by visiting the website designed for this purpose.

6- Data obtained from all the three instruments were then recorded, and analyzed as will be discussed. 


\section{Results and Discussion}

Twenty Native speaker EFL instructors at Taibah University have participated in the study. Table 2 shows their backgrounds.

Table 2. Participants' Bio data

\begin{tabular}{lllll}
\hline Number of Teachers & Gender & Nationalities & Experience in ELT & Experience in ELT in KSA \\
\hline 20 & Male & 2- Americans & 12-more than 5 years & 10- More than 3 years \\
& & 12- British & 6-more than 3 years & 5-2 years \\
& & 3- Australians & 2-2 years & 5- One year \\
& 3- New Zealanders & \\
\hline
\end{tabular}

\subsection{Results of the Observation Sheets}

Based on three different observations for each participant, the average of the three evaluators / observers was calculated and is shown in Table 3.

Table 3. Standard-based evaluation scores of EFL instructors

\begin{tabular}{|c|c|c|c|c|c|c|}
\hline Participants & Evaluator 1 & Evaluator 2 & Evaluator 3 & $\begin{array}{l}\text { Average of } \\
\text { Evaluators \% }\end{array}$ & \multicolumn{2}{|c|}{ Overall rating } \\
\hline 1 & 91 & 92 & 93 & 92 & 5 & Excellent \\
\hline 2 & 86 & 88 & 87 & 87 & 4 & V. good \\
\hline 3 & 71 & 74 & 71 & 72 & 3 & Good \\
\hline 4 & 78 & 82 & 80 & 80 & 4 & V. good \\
\hline 5 & 89 & 87 & 88 & 88 & 4 & V. good \\
\hline 6 & 97 & 99 & 98 & 98 & 5 & Excellent \\
\hline 7 & 85 & 88 & 85 & 86 & 4 & V. good \\
\hline 8 & 94 & 93 & 89 & 92 & 5 & Excellent \\
\hline 9 & 85 & 83 & 87 & 88 & 4 & V. good \\
\hline 10 & 95 & 99 & 97 & 97 & 5 & Excellent \\
\hline 11 & 89 & 86 & 89 & 88 & 4 & V. good \\
\hline 12 & 57 & 62 & 61 & 60 & 2 & Satisfactory \\
\hline 13 & 85 & 85 & 88 & 86 & 4 & V. good \\
\hline 14 & 56 & 57 & 61 & 58 & 2 & Satisfactory \\
\hline 15 & 75 & 79 & 77 & 77 & 3 & Good \\
\hline 16 & 74 & 76 & 78 & 76 & 3 & Good \\
\hline 17 & 87 & 92 & 91 & 90 & 5 & Excellent \\
\hline 18 & 78 & 82 & 80 & 80 & 4 & V. good \\
\hline 19 & 60 & 65 & 64 & 63 & 2 & Satisfactory \\
\hline 20 & 67 & 72 & 71 & 70 & 3 & Good \\
\hline
\end{tabular}

Table 3 shows that most of the EFL instructors at Taibah ELC were of a high level in their teaching performance. Five are rated as excellent teachers; eight are rated as "very good", four are rated as "good", three are rated as "satisfactory". None are rated as "unsatisfactory".

\subsection{Results of the Scale of Religious Commitment}

Participants' responses to the questionnaire were calculated and are shown in table 4. 
Table 4. EFL instructors' scores in the questionnaire of religious commitment as compared to their teaching performance

\begin{tabular}{llll}
\hline Participants & RC scores out of 90 & $\begin{array}{c}\text { R C scores } \\
\%\end{array}$ & $\begin{array}{l}\text { T's } \\
\text { performance \% }\end{array}$ \\
\hline 1 & 80.00 & 88.88 & $\mathbf{9 2}$ \\
2 & 80.00 & 88.88 & $\mathbf{8 7}$ \\
3 & 72.00 & 80 & $\mathbf{7 2}$ \\
4 & 81.00 & 90 & $\mathbf{8 0}$ \\
5 & 90.00 & 100 & $\mathbf{8 8}$ \\
6 & 90.00 & 100 & $\mathbf{9 8}$ \\
7 & 83.00 & 92.22 & $\mathbf{8 6}$ \\
8 & 89.00 & 98.88 & $\mathbf{9 2}$ \\
9 & 84.00 & 93.33 & $\mathbf{8 8}$ \\
10 & 90.00 & 100 & $\mathbf{9 7}$ \\
11 & 87.00 & 96.66 & $\mathbf{8 8}$ \\
12 & 85.00 & 94.44 & $\mathbf{6 0}$ \\
13 & 85.00 & 94.44 & $\mathbf{8 6}$ \\
14 & 87.00 & 96.66 & $\mathbf{5 8}$ \\
15 & 76.00 & 84.44 & $\mathbf{7 7}$ \\
16 & 77.00 & 85.55 & $\mathbf{7 6}$ \\
17 & 89.00 & 98.88 & $\mathbf{9 0}$ \\
18 & 81.00 & 90 & $\mathbf{8 0}$ \\
19 & 61.00 & 67.77 & $\mathbf{6 3}$ \\
20 & 69.00 & 76.66 & $\mathbf{7 0}$ \\
Mean & 81.8 & 90.88 & $\mathbf{8 1 . 4}$ \\
S D & $\mathbf{8 . 5 1}$ & $\mathbf{8 . 6 1}$ & $\mathbf{1 1 . 7 8}$ \\
\hline
\end{tabular}

Table 4 shows that participants have a high level of religious commitment; a big number of them (13) scored above $90 \%$, while the lowest value was $67 \%$. This shows that these EFL teachers are highly religious. In fact some of them complained that the scale had few examples of religious commitment and that there actual practices are more than what is listed. These data provide answers to question two of the study which asked about the extent to which participants represent moral committed practices. The average percentage of participants' religious commitment is $90 \%$. This also provides answers to hypothesis two which predicted that participants would represent high levels of religious commitment. The hypothesis is thus sustained.

To calculate the correlation between instructors' standard-based performance and their religious commitment, Alpha coefficient was run and the following results were attained:

Table 5. Pearson's correlation value between religious commitment and teaching performance

\begin{tabular}{llll}
\hline & & Rel_Commit & Performance \\
\hline \multirow{3}{*}{ Rel_Commit } & Pearson Correlation & 1 & $.565^{* *}$ \\
& Sig. (2-tailed) & & .009 \\
& N & 20 & 20 \\
\multirow{5}{*}{ Performance } & Pearson Correlation & $.565^{* *}$ & 1 \\
& Sig. (2-tailed) & .009 & \\
& N & 20 & 20 \\
\hline **. Correlation is significant at the 0.01 level (2-tailed).
\end{tabular}

Table 6. Spearman's correlation value between religious comm. itment and teaching performance

\begin{tabular}{lllll}
\hline & & Rel_Commit & Performance \\
\hline \multirow{4}{*}{ Rel_Commit } & Correlation Coefficient & 1.000 & $.617^{* *}$ \\
& & Sig. (2-tailed) &. & .004 \\
& N & 20 & 20 \\
& Correlation Coefficient & $.617^{* *}$ & 1.000 \\
& \multirow{2}{*}{ Performance } & Sig. (2-tailed) & .004 &. \\
& & N & 20 & 20 \\
\hline **. Correlation is significant at the 0.01 level (2-tailed). & &
\end{tabular}


Pearson's coefficient for the correlation between teachers' performance evaluation and their scores in the questionnaire of religious commitment equals 0.565 which is highly significant at 0.009 level. Likewise Spearman's coefficient equals 0.617 which is also significant at 0.004 . This shows that there is a positive correlation between EFL instructors in Taibah LC and their religious and moral commitment. This can also be represented graphically in figure 1.

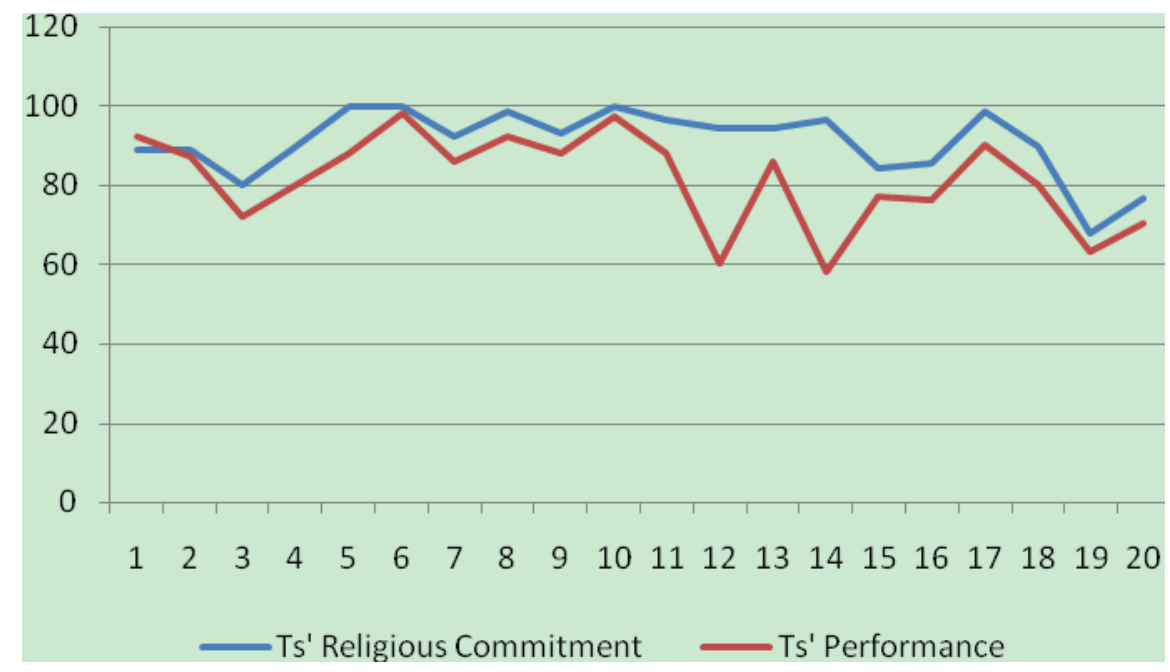

Figure 1. Teachers' religious commitment as compared to their performance

Results of the observation sheet and the scale of religious commitment and the statistical correlations between them provide answer to the fourth question of the study. Question four asked about the nature of the correlation between participants' moral commitment and their standard-based practices. The data show that the correlation is positive and significant at 0.004 and 0.009 levels depending on the method used for calculating the correlation. This also provides insight for hypothesis four of the hypotheses of the study. This hypothesis predicted that there is a positive correlation between participants" moral commitment and their standard-based practices. The hypothesis is thus sustained.

\subsection{Results of the Morality Opinionnaire}

Since this questionnaire was open-ended eliciting clarifying interpretations and explanations of participants' points of view, a detailed qualitative analysis of the answer to each question is presented.

Participants seemed to fall within one of three categories; the conservatives, the liberals, and the moderates. The conservatives are characterized by abiding by the literal religious texts, sometimes using Arabic words to express themselves because they consider the Arabic expression as having no equivalent in the English language when it comes to reporting spiritual / religious beliefs. Some even may write the Arabic expressions in Arabic alphabet; thus distancing themselves from the very Latin-based writing of English. In their responses, they tend to give short answers heavily-loaded with cultural allusions drawn from the early Islamic and Arabic culture. Some may overtly express their unrest with the use of English and their inclination towards getting rid of it. Participants who fall into this category normally achieve the highest in the scale of Religious commitment, but have various levels of achievement in the performance observation sheet. (2 participants got satisfactory performance evaluation)

Participants who fall into the second category, the liberals, tend to express their impressions about Islam / faith as a driving force for exerting effort and achieving excellence in the job. However, they see a disconnection between faith and work, attributing their high levels of achievement to the rich background and the training they went through rather than to any moral or spiritual commitment. Participants who fall into this category achieve moderately high in the questionnaire of religious commitment, and achieve the same in the observation tasks. (one participant got satisfactory performance evaluation)

Participants in the third category, the moderates, tend to have an open-minded view of faith. They tend to see faith / Islam as the code of conduct or a way of life without which they wouldn't achieve any better in their 
career. Unlike the first category, they tend to hold a holistic view of religion incorporating both the needs of this life and the aspirations of the Hereafter. They represent an inclusive viewpoint where faith-oriented people are the ones responsible for being the models for others in the same career and in life in general. Unlike the second category, they do not distance religion from everyday practices in the different walks of life.

\section{Q 1: What does the term "religion" mean to you based on your Islamic faith?}

Examples representing the first category included answer like: "following Quran and Sunnah", "to believe in Allah, follow the Sunnah... follow the consensus of the companions, and the scholars of Ahl as-Sunnah" ", "total submission to Allah upon monotheism.. and disassociating oneself from Shirk", "a system of worship for the Creator ... in His Lordship, His Worship, and His attributes ", " a belief system ...that centers around Tawheed and Taqwa", "the ijma of the sahaba".

Examples representing the second category include answers like: "a code of conduct", "believing in God and His messenger", "there is no God but Allah", "pleasing your lord within your worship", "conducting one's life in accordance to God's Law".

Examples of the third category include answers like: "a way of life", "the way you worship Allah which includes every aspect of life", "the fundamental call to the ones of God and its principles", "the ultimate truth [that] enables us the humans in living meaningful lives in this world and in achieving salivation in the Hereafter", "it is the most important thing in my life...it is the criterion against which I measure everything I do".

\section{Q 2: What does the term "Islamic commitment" mean to you as a Muslim?}

In answering this question, the conservatives tended to emphasize the qualities of an adherent Muslim with many references and allusions to traditional Islamic literature. Examples include the following: "Istiqama", "to adhere to the Quran and Sunnah in all affairs", "adhering to the fundamentals of Islam", "to observe the sunnah of the prophet", “Aqeeda and Manhaj", "conducting one's life in accordance to God's law".

Participants in the second category tended to spell out certain qualities and attributes of the committed person. Examples include: "holding fast to the underlying message that there is no God but Allah, and living...by that percept.", "to do the things Allah wants us to do diligently and consistently", "to excel in obedience to Allah", "keep your word with all people", "keeping promises".

Participants in the third category tended to report general qualities that reflect dealings with God, people and oneself. Examples include: "uphold my responsibilities both publicly and privately", "applying my deen in my dealings with people, especially in my work", "a responsibility toward your lord and society as a whole", "keeping faith and making it foremost in my life and work", "devotion and steadiness in practicing Islam", "an ongoing pursuit to improve oneself".

\section{Q 3: How can you relate your work as an FL teacher to your Islamic background?}

In responding to this question, the conservatives were vocal regarding their anti-western approach. The long historical clash between the West and the Muslim world is reflected in these participants' responses. They seem to undergo a conflict between their identities as Muslims and their identities as Westerners. Some of them even prefer to write in broken Arabic to writing in his mother tongue. They feel the responsibility to do their job by teaching the language to Arab Muslims, but, at the same time, refrain from teaching the culture of the foreign language. Examples of their responses include: "I try to show that the West is not always better...by showing the completeness of Islam in its belief system and morals", "I try to incorporate all the principles of Islam, creed and belief in my conduct with the students", "Alhamdolillah ${ }^{10}$ I work in an environment where I can practice my religion freely", "I use examples of Islamic convention to point out Western equivalents", "I teach Islamic etiquettes, morals and characters", "dealing with the language situations forced on us by the curriculum from an Islamic point of view", "I teach my students English, but at the same time, make them realize that they should be proud of their religion and own language, and not so fascinated by the West".

Responses of the liberal participants tended to emphasize that their faith requires being a good language teacher as it is the job they have to fully deliver. They do not seem to suffer the Western conflict, and their connection between religion and their career is general in nature or taken for granted. Examples include: "being a practicing Muslim helps me be a better teacher", "to teach language to others so they can use it best", "I cannot separate the two", "students require a good model to teach and help them learn", "since I work in KSA and Islam plays a central role in the government, so my work is closely related to religion".

Responses of the moderates reflected an open stand that does not suffer the Western complex and at the same time does not ignore the deep role of religion. For them, their job is not just a career nor is it a place for conflict; 
it is rather a message that needs to be delivered to please both the Creator and the created. Examples include: "Were I to describe my overall experience as an ESL teacher figuratively, I would say it is a large, colorful collage of vibrant, exhilarating and meaningful pictures and splashes of colors. I could never feel restrained or narrowed by my Islamic background", "Practically from teaching conversation to writing to words in context to anything I find all my teaching and learning comes from the spring head of my deen", "Utilizing teaching methods as an EFL teacher to teaching Islamic materials", "carrying the amanah ${ }^{11}$ of developing characters of the youth".

\section{Q 4: What do you consider to be the qualities of the best Muslim language instructor?}

Although all the three categories listed general qualities that can be possessed by any good language teacher whether Muslim or non-Muslim, the first category emphasized qualities that are related to faith, and that reflect the West-East Conflict. The second and the third categories were not different in responding to this question. They mentioned general attributes and qualities needed by all language instructors. Examples of the conservatives' responses include: "helping students when needed in Islamic issues", "to have Islamic manners... avoid the things in a language that may oppose the religion", "ability to compare Islamic culture and the Western culture positively", "be knowledgeable about the religion...applying the Islamic culture into teaching when necessary", "avoiding situating language in a Western Pop culture and secular sexual morality", "A person that shows the Ss that English is important but just a tool: i.e. that one can study a language without having to acquire its negative cultural aspects".

On the other hand, the moderate and the liberal participants' responses were the following: "motivating, facilitating", "someone who cares", "someone the students can relate to", "confidence", "attending professional development workshops", "trustworthy and punctual", "dedicated", "Patient", "friendly, compassionate, well-prepared", "to be an educator as well as an FL instructor", "I list them in this order: 1. Unsatisfied (yearns for better until achieves the best) 2. Instills the love of knowledge in the students 3. Is neatly dressed, writes and speaks well, and is easy going. All these traits are helpful in triggering learning”.

\section{Q 5: How do you evaluate yourself as a Muslim language instructor?}

In answering this question, participants showed three different self-images. One group tended to emphasize the fact that no one is perfect, that they try to be good persons and that they see themselves as still having a long way to go. This trend is based on the idea that committed people view themselves humbly as inefficient persons yearning for perfection. Examples that represent this group include the following responses: "very weak", "aware", "there is always room for improvement", "Alhmadlillah, Ok". The second group of participants, on the other hand, represented a high self-image. They describe themselves as "very good", "true to my word, and committed to my work", "well articulated, confident and a veracious reader. My classes are usually student centered where I try to give them as much knowledge and information as I can".

There was a third group who explained that they were aware that they are "good", but are also aware of their limitations. So they emphasize the concept of continuous professional development in specific areas. Examples of this group responses include: "I need to communicate the non-judgmental aspect of my approach better than I do", "I try to develop good relationships with my students", "I try to bulb my faith as well as language instruction", "I try to be on time, modest, trustworthy, understanding". It is noticeable that some participants $(20 \%)$ favored not to answer this question as it involves an evaluation of oneself which they believed should not be done by the person to himself.

\section{Q 6: What is your philosophy of teaching?}

This question was posed to explore the depth of teacher's mentalities and the projection of moral religious commitment on teacher's philosophies. In responding to this question, there seem to be two dominant views; the student-centered view, and the teacher -centered view. The former refers to practices revolving around the student and the classroom environment, the latter focusing on personal practices of teachers to achieve informed teaching. Examples representing the student-centered view include: "my mission is task-based, student-centered", "to make the learning process as learner-centered as possible", "students come first", "open engagement for collaborative study and a learner-centered approach to teaching materials", "let the students show you how to teach them the way they will best understand", "I don't teach, I help other learn".

Examples for the teacher-centered view include: "motivate, facilitate and accommodate students", "motivation + challenge = learning", "do you best", "confidence + motivation = success", "I use relative examples to the environment", "I use the direct method", "I try my best to teach according to knowledge-based research", "I try to make a personal connection with each of my students". It is worth noting that one participant emphasized the 
use of both strategies by using " a dual approach of teacher centered instruction and student centered learning". Another participant confessed overtly that he "does not have one". This may be due to the old tradition of not approving the word "philosophy" and its related peculations in matters of belief, in conservative Islamic settings. Five participants did not answer this question.

The answers to this question reflect an awareness of language developments and language teaching theories rather than any direct relation to faith or religion. Question 7 tries to unlock the relation between the given philosophy statements and faith.

\section{Q 7: How is your philosophy related to you Islamic faith?}

There are still three different groups that responded to this question, by relating their stated philosophies with their faith. The conservatives focused on the role of religion as a guiding code regardless of their job. Some stated that "it is related in terms that it won't be against the trend of the deen". Others were vocal concerning their unrest with the term philosophy; "there is no such a thing as philosophy", they even scolded the researchers by saying "do not mix English with religion". Some preferred to use the Arabic word "Ihsan" 12 ".

The liberals viewed the relation between their philosophies and their faith in terms of professionalism needed for success in a job based on sound creed. They find the relation "integral: confidence is the opposite of shyness, motivation is the opposite of apathy, and success is the opposite of failure". Some focused on the role of the environment; "the culture of my Muslim students makes me actively engaged in the learning process". Some focused on the end product; "a person would be tested based on his production". Still some others confessed that there is no point in relating their philosophy to a certain religion; "it is the same procedure followed if Muslim or not". Some others confessed that "it is not related really".

The moderates, on the other hand, stated a closed relation between their philosophies and their faith. They derive their teaching philosophy from many concepts in Islam such as duty; "it is a duty among the teachers to make the best for his students". Others focused on the concept of identity; "it defines who I am and the way I live". Others focused on the concept of responsibility; "it is the responsibility of a father in nurturing his children upon Islamic values". Some viewed religion as the foundation based on which their philosophy is rested; "the best Muslim is the one who chooses his philosophy from and informed foundation of faith". Others used historical allusions to relate their philosophies to their faiths; "to keep it succinct: the first wahi ${ }^{13}$ says it all". Five participants didn't provide an answer to this question.

Responses provided for the 7 questions in the open-ended questionnaire provide answers to questions one and three of the study. Question one asked about the nature of moral commitment held by ELT instructors. Responses showed that there are three categories of religious orientation: the conservatives, the liberals and the moderates. Question three of the study asked about how participants view their professional practices in light of their religious practices. Responses to questions 3-7 of the questionnaire provide answer to this question. There are varying degrees of identification with religious practices within the professional career as detailed above.

Responses to the questionnaire also provide data for hypnoses two and three of the hypotheses of the study. Hypothesis one predicted that ELT native speaking instructors' moral commitment to be of diverse nature. This hypothesis is sustained as responses showed different orientations of spiritual commitment among the participants. Hypothesis three predicted that participants would view their professional practices as falling short of their religious commitment. This hypothesis is rejected as most teachers indicated that they value their professional practices and see them as representatives of their religious commitment, although a few number indicated that they need more development.

Based on the information gained from the open-ended questionnaire, the following categorization can be used to describe the sample of the study with regard to their religious orientations.

Table 7. Categorization of teachers according to their religious orientations

\begin{tabular}{llllll}
\hline Questions & \multicolumn{2}{l}{ Religious orientation } & & Total \\
& Conservatives & Liberals & Moderates & Answer denied & \\
\hline Question 1 & 7 & 5 & 8 & 0 & 20 \\
Question 2 & 6 & 5 & 9 & 0 & 20 \\
Question 3 & 7 & 6 & 7 & 0 & 20 \\
Question 4 & 6 & 1 & 13 & 0 & 20 \\
Question 5 & 5 & 3 & 7 & 5 & 20 \\
Question 6 & 4 & 5 & 6 & 5 & 20 \\
Question 7 & 5 & 5 & 5 & 5 & 20 \\
Average number & 5.714286 & 4.285714 & 7.857143 & 2.142857 & 20 \\
\hline
\end{tabular}




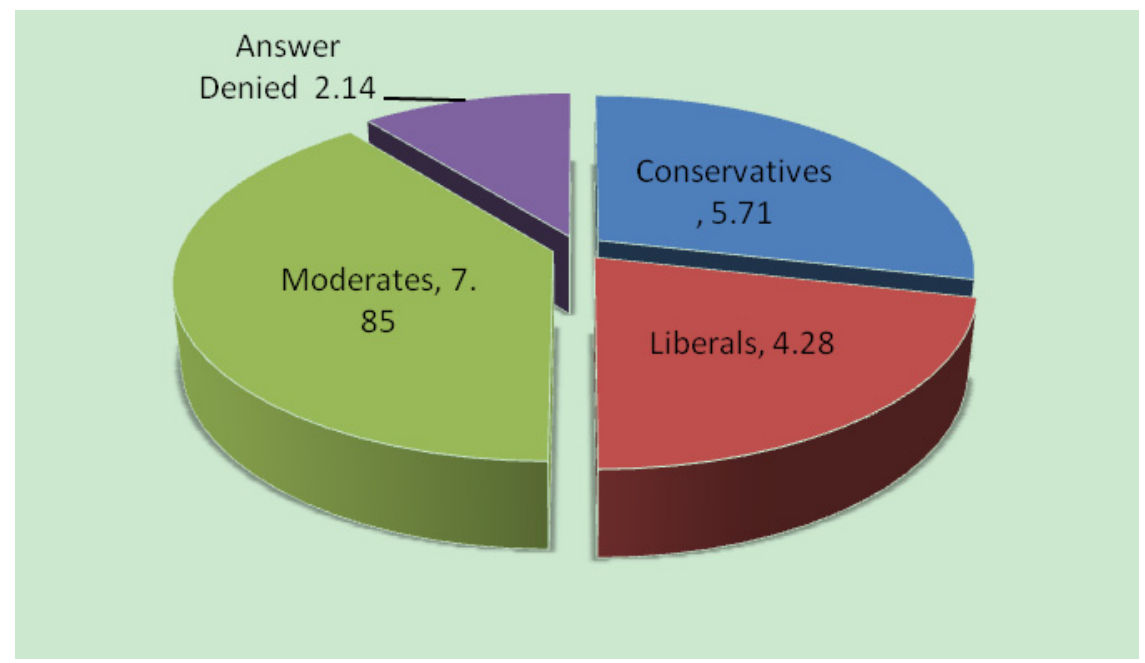

Figure 2. Average number of Participants according to religious orientation

Table 7 and figure 2 show that most teachers fall into the moderate category whose religious practices are integrated with their professional ELT practices (about 8 out of 20). About 6 out of 20 are considered conservative who highly regard their traditional religious practices and who seem to distance their morality from ELT as a Career. Likewise about 4 out of 20 are considered liberals who have moderate religious practices and isolated professional ELT practices.

\section{Recommendations}

Based on the results of the study, the following recommendations are suggested:

1- More in-depths studies are needed to be conducted in the field of ELT and spirituality with native and non-native English instructors.

2- Female ELT teachers' morality needs to be studied extensively compared with male teachers' spirituality.

3- More studies are needed to investigate the nature of the language learner morality and its effect on enhancing certain language skills

4- Certain misconceptions about the nature of Islam as a religion and the English language as an imperialistic language need to be corrected both for the native Muslim English instructor and the Arab language learner.

5- ELC recruitment units in Saudi universities may need to conduct periodical orientation meetings with newly-hired teachers in order to correct such misconceptions.

\section{Conclusion}

In this study, we investigated moral commitment of ELC native speaking instructors at Taibah University. We tried to explore the nature of their spirituality and its relation to their professional language teaching practices. Although the overall results show a highly positive correlation between participants' religious morality and their standard-based performance, there are still areas that need discovery in the non-Arab Muslim mentality and its manifestations in professional practices. Smith \& Osborne (2007), in their review of the current literature on how spirituality and second language learning or teaching relate, state that the research in this area is still sporadic and lacks coherent broad inquiry. Our current study of spirituality and ELT is stalled at the initial stage of examining spiritual aspects of the Language instruction in a sample Arab university. But as to how this occurs, there is still much to explore.

\section{References:}

Abdellah. A. (2012). Foreign language teaching strategies followed by Muslim religious scholars- analysis and implications. Paper presented at the Azad Oxford University conference on Islamic Scholasticism. Dubai, April 2012.

Chomsky, N. (2000). New horizons in the study of language and mind. Cambridge: Cambridge University Press. 
Cranton, P., \& Carusetta, E. (2004). Perspectives on authenticity in teaching. Adult Education Quarterly, 55(1). http://dx.doi.org/10.1177/0741713604268894

Croft, W., \& Cruse, A. (2004). Cognitive linguistics. Cambridge: Cambridge University Press.

Fenstermacher, G., Osguthorpe, R., \&Sanger, M. (2009). Teaching morally and teaching morality. Teacher Education Quarterly, Jun 22, 2009.

Francis. M. (2007). The moral and ethical dimensions of language teaching. Australian Journal of Education, 51(2), 178-189. http://dx.doi.org/10.1177/000494410705100206

Hong, M. (2007). Spirituality and English language teaching- A Christian exploration. Unpublished PhD thesis. Purdue University, Indiana.

Johnston, B. (2003). Values in English language teaching. Mahwah, NJ: Lawrence Erlbaum. http://dx.doi.org/10.1017/S0261444803001976

Khan, M. (2004). Moral Development of Students at Islamic Schools in America: Comparing Immigrant and American Muslim Teachers' Perspectives. Paper presented at the annual meeting of the American Sociological Association, San Francisco, CA. Retrieved 12th Jan. 2013, from http://www.allacademic.com/meta/p109548_index.html

Kramsch, C. (Ed.). (2002). Language acquisition and language socialization: Ecological perspectives. New York: Continuum.

Labov, W. (1972). Sociolinguistics patterns. Philadelphia, PA: University of Pennsylvania Press.

Lakoff, G. (1987). Women, fire, and dangerous things: What categories reveal about the mind. Chicago: University of Chicago Press. http://dx.doi.org/10.7208/chicago/9780226471013.001.0001

Layder, D. (1993). New strategies in social research: An introduction and guide. Oxford: Polity Press.

Leather, J., \& van Dam, J. (2003). Towards an ecology of language acquisition. In J. Leather, \& J. van Dam (Eds.), Ecology of Language Acquisition (pp. 1-30). Dordrecht: Kluwer. http://dx.doi.org/10.1007/978-94-017-0341-3

Palmer, P. (2003). Teaching with heart and soul: Reflection of spirituality in teacher education. Journal of Teacher Education, 54, 376. Retrieved March 25, 2004, from http://jte.sagepub.com/cgi/reprint/54/5/376.pdf/

Palmer, P. (1983). To know as we are known: A spirituality of education. San Francisco, CA: Harper \& Row.

Pennycook, A., \& Coutand-Marin, S. (2003). Teaching English as a missionary language (TEML). Discourse studies in the cultural politics of education, 24, 338-353. http://dx.doi.org/10.1080/0159630032000172524

Pope Paul VI. (1965). Declaration on the relation of the church to non0christian religions. NOSTRA AETATE. Retrieved 12th March 2013, from http://www.vatican.va/archive/hist_councils/ii_vatican_council/documents/vat-ii_decl_19651028_nostra-ae tate_en.html

Ren, W. (2009). Reinforcement on Teachers' Morality Construction - An Eternal Subject in Educational Development. Asian culture and History, 1(2), July, 2009.

Smith, \& Osborne. (2007). Spirituality, social justice and language learning. Contemporary Education. Charlotte: Information Age Publishing.

Stevick, E. (1990). Humanism in language teaching: A critical perspective. Oxford: Oxford University Press.

Yost. D. (1997). The moral dimensions of teaching and preservice teachers: can moral dispositions be influenced? Journal of Teacher Education, 48, 1997. http://dx.doi.org/10.1177/0022487197048004006 


\section{Appendix A}

\section{Scale of religious commitment:}

Dear respected language instructors,

Please take some time to answer the following questionnaire. This is part of a study on the relationship between morality and EFL quality performance in Taibah University ELC. We understand that people prefer not to give data regarding personal religious practices for sincerity purposes. However, you are kindly requested to provide these inputs for academic purposes. Your data and details will be kept confidential and will be used for research purposes only. Your cooperation is highly valued.

1. I perform the five prayers daily

2. I perform the five prayers with a group

3. I perform the five prayers in a mosque

4. I perform the five prayers on time

5. I perform additional daily prayers (Sunan)

6. I perform late night prayers (tahajud)

7. I lead the prayer among my colleagues

8. I observe performing the dawn prayer on time

9. I perform fasting during Ramadan

10. I perform fasting three days each month (the $13^{\text {th }}, 14^{\text {th }}$ and $15^{\text {th }}$ )

11. I perform fasting on Mondays and Thursdays

12. I perform fasting in celebrated days like the $9^{\text {th }}$ of Zul Hijjah, the $10^{\text {th }}$ of Muharam and 6 days in Shawwal.

13. I observe paying the due zakat in my money each year

14. I give alms to the poor

15. I donate to relief agencies and humanitarian societies

16. I say morning and evening supplications (azkar)

17. I visit the prophet's mosque

18. I read the Quran daily

19. I am good at reciting the Quran

20. I can teach principles of recitation (Tajweed) to others

21. I memorize big chapters from the Quran

22. I quote the Quran and the prophet's traditions in my speech

23. I try to apply Quranic instructions in my life

24. I listen to audio and video media on religious topics

25. I help others do good deeds

26. I keep my promises

In front of each statement, please write: A (Always),

$\mathbf{S}$ (Sometimes), or

$\mathbf{N}$ (Never).

27. My colleagues seek my advice concerning religious matters

28. My wife wear(s) a head scarf (hijab) [ YES - I AM THINKING ABOUT IT- NO- NA]

29. I perfumed Hajj [ONCE- TWICE- MANY TIMES - NEVER]

30. I performed Umra [ONCE- TWICE- MANY TIMES - NEVER] 


\section{Appendix B}

Dear Language instructor,

The researchers are conducting a study to investigate the relationship between Islamic commitment and the quality of the foreign language instructor at Taibah University ELC. You are kindly requested to provide answers to the following questions in as much detail as you can. Your response will be used for research purposes only and your personal information will be kept confidential.

Name (Optional):

Gender: $\mathrm{M} \quad \mathrm{F}$

Nationality:

Years of experience teaching EFL:

Years of ELT experience in KSA:

1. What does the term "Religion" mean to you based on your Islamic faith?

2. What does the term "Islamic commitment" mean to you as a Muslim

3. How can you relate your work as An EFL teacher to your Islamic background?

4. What do you see as the qualities of the best Muslim language instructor?

5. How do you evaluate yourself as a Muslim language Instructor?

6. What is your philosophy of teaching?

7. How is your philosophy related to your Islamic faith?

\section{Appendix C}

\section{The observation sheet}

Assessment Items
Standard One: Lesson Objectives
1. Lesson had objectives that were made clear to students
Standard Two: Lesson Delivery
2. The teacher spoke clearly, correctly and confidently
3. The teacher was able to adapt the lesson to the students' level
4. Explanations and examples given were made clear to the students
5. There was evidence of lesson planning
6. The class understood what was required of them during the lesson
7. The teacher related the lesson to the students' experiences/interests
8. The teacher demonstrated subject knowledge and understanding
9. Students were engaged during the lesson
10. The teacher carried out comprehension checks
11. The teacher gave effective feedback to the students
12. The teacher used the board/visual aids effectively
13. Learning activities/tasks were set up well
Standard Three: Teacher-Student Interaction
14. There was a good rapport with the students
15. Teacher talk time (TTT) and student talk time (STT) was balanced
16. Students were regularly involved in the lesson
17. The lesson allowed for a variety of learning styles
18. Effective classroom management was demonstrated
19. Autonomous learning was encouraged

Standard Four: Closure

20. The teacher reviewed the lesson and encouraged student reflection on the objectives taught 


\begin{tabular}{llllll}
\hline Overall & Excellent & Very Good & Good & Satisfactory & Unsatisfactory \\
Rating & 5 & 4 & 3 & 2 & 1 \\
\hline Score range & $90-100$ & $80-89$ & $70-79$ & $50-69$ & $49-0$ \\
\hline
\end{tabular}

\section{Notes}

1. The tradition of the prophet Muhammad (Peace and blessings be with him).

2. Ahl as-Sunnah: a term that refers to non-Shia Muslims.

3. Shirk: a term that refers to believing in more than one true God.

4. These are the types of monotheism according to the traditional books of Islamic jurisprudence.

5. Tawheed and Taqwa: Monotheism and Piety.

6. the ijma of the sahaba: The consensus of the companions of the Prophet Muhammad.

7. Istiqama: straightforwardness

8. Aqeeda $=$ Creed, and Manhaj $=$ an ideology

9. Deen ; religion and religious practices

10. Alhamdolillah: Thank God

11. Amanah: devotion to a mission.

12. Ihsan: Working for perfection

13. Wahi: revelation; and the reference here is to the first word that was revealed to the prophet; "Read", which denotes learning and teaching. 